Cloth, gender, politics: the Armagh Handkerchief, 1976

Louise Purbrick, University of Brighton

Le mouchoir d'Armagh. Tissu, genre et politique

Clio: Femmes, Genre, Histoire, 40, 2014, ISBN 978-2-7011-9045-7, on-line ISSN 17775299

In the centre of a large white cotton handkerchief a gun lays over a flag (Figure 1). The gun is an AK47, the flag an Irish tricolour. Both are comprised of even blocks of colour created by felt tip pens. Above, an unfurled banner outlined in black felt tip announces "'A' Company" and the date "1976" (Figure 2). The date is divided in half, written on a flourish of fabric at each banner's end. "ARMAGH JAIL", stencilled in orange above the banner and below the strap of the gun, completes handkerchief's centrepiece: it is surrounded by names. Forty-five women have signed in Biro ballpoint pen. Most have added a neighbourhood and number of years under or after their names; many draw a line under these details of their life. Along the bottom hem is a dedication: "TO GEORDIE \& BERNADETTE, FROM CHRISTINE ARMAGH JAIL 1976."

The handkerchief can be easily recognised as a politicised and gendered object. A cursory glance is quite sufficient to see the iconography of a national armed struggle and the multiple marks of female biographies. That quick look might also capture some of contradictions of material form. The light fabric is weighed down with significance, with all those names: Angela, Anne, Brenda, Dolours, Eíbhlín, Eileen, Evelyn, Geraldine, Jackie, Jane, Josephine, Kate, Maíread, Maria, Madeline, Margaret, Marion, Maríe, Mary, Milly, Nuala, Patricia, Pauline, Philomena, Rita, Rosie, Shelia, Susan. Lines of similar width and colour formed these names, indicating they wrote with the same pen. Biros are ubiquitous, quotidian, common; but this one was shared, passed from hand to hand. Its point was pressed upon a common cloth. The handkerchief is a simple square 
of white cotton and one of plainest fabrics possible. Felt tip pens are common, too; they are a cheap, quick, standardised means of creating contrasting colour. The Armagh handkerchief is both mass-produced and it is handmade; it is resolutely ordinary and absolutely unique. It is full of material, historical and apparent contradictions, only one of which is the juxtaposition of women and violence, the female names that encircle an automatic assault rifle.

This essay is about the meanings of the Armagh handkerchief. It reflects upon its contradictions, how, in particular, its fragile materiality can contain such political force. My focus is the material. As an art and design historian, I attend to the material form, to how the details of an image or object may be rendered with specific techniques and through a particular medium. In attending to the material, I borrow some anthropological ways of thinking; I try to "think with" material culture. This is to attempt to understand material as already cultural. A particular material form not only represents a category, such as gender, constituted elsewhere, in some higher immaterial place; it does the work of categorisation: material forms are cultural categories ${ }^{1}$. Since my focus is material, my historical source is the handkerchief itself. Its materiality is both physical, its has general properties of cloth, and historical; there are specific conditions of its existence: it was decorated and circulated in a particular time and place. The material form of the handkerchief needs to be explained by its conditions of production, how it was made by women imprisoned in Armagh during the conflict "in and about" Northern Ireland" ${ }^{2}$. It is a part of a wider material culture of conflict of which my understanding has developed through working with former political prisoners and within conflict resolution groups to

\footnotetext{
${ }^{1}$ Douglas and Isherwood 1996; Holbraad, Wastell and Henare 2007.

2 The phrase 'in and about' Northern Ireland is used by Healing Through Remembering (http://www.healingthroughremembering.org) and adopted here to acknowledge that status of Northern Ireland is contested.
} 
consider how these forms may be preserved, recorded and interpreted. ${ }^{3}$ Thus the analysis of the Armagh handkerchief offered here is an examination of how its gendered political properties are constituted by its material form. The Armagh handkerchief is also a borrowed form. It was not the first of its kind.

\section{Another handkerchief}

Amongst the 106 illustrations included in Rozsika Parker's, The Subversive Stitch (1984), there is a silk handkerchief made by one imprisoned woman and signed by many others ${ }^{4}$ (Figure 3 ). Its centrepiece is posy of embroidered appliquéd flowers; purple lilies encircle an embroidered script and signature: "Worked in Holloway Prison by Jane Terrero." Around the petals, leaves and stems, Jane Terrero stitched an account of her imprisonment: "Arrested March $1^{\text {st }} 1912 /$ Sentenced by Judge Lawrie on Wednesday March $27^{\text {th }}$ to four months." The icon and emblems of the suffragette movement provide the title and frame for the flowers and their maker. At the top are the initials of the Women's Social and Political Union, "W.S.P.U.", their motto, “Deeds not Words"; fixed along the bottom of the handkerchief's border, a purple white and green ribbon, is a postcard portrait of WSPU leaders, Emmeline and Christobel Pankhurst. Between border and centrepiece are two columns of names of the suffragette prisoners who participated in hunger strikes and "were fed by force." Their signatures, Roszika Parker suggests, brought together 'the tradition of political petition and protest with a female social tradition by which guests would embroider their signatures for their hostess to commemorate a visit. ${ }^{5}$ Parker draws attention to the dualities of their embroidery upon the handkerchief; she argues that suffrage stitchery was dialogue between subjugation and resistance. Thus, to embroider was to employ the sign of the "supposed weaker

\footnotetext{
3 Purbrick 2006; Purbrick 2007.

${ }^{4}$ Parker 2012: 192-3.

${ }^{5}$ Parker 2012: 200.
} 
sex" to celebrate its strength. ${ }^{6}$ Indeed, Jane Terrero's commemoration of feminine resistance to authority was articulated in a particular feminine form: the act of smashing windows was represented in small stitched hammers; the arrows of prison dress and bars architecture are shown in similar fashion.

Maureen Daly Goggin's recent account of Jane Terrero's Holloway handkerchief notes that it can be read as many things: a political protest, an art object, an historical record. But she analyses it as an "identity performance", a material "fabrication" of self. ${ }^{7}$ Terrero's stitching of the handkerchief's centrepiece, an example of "fancywork", constituted her as middle-class and feminine ${ }^{8}$ but the fabric itself had already done some of this performative work for her. Daly Goggin points to histories of the handkerchief that have identified the femininity of the fabric: it is both "'an extension of the self" and "the mark of a lady"' ${ }^{9}$ Importantly, Daly Goggin recognises that the handkerchief is already a cloth of some significance. Embroidery is evocative, a seductive device for understanding the meaning of handkerchiefs decorated by imprisoned women because, as Parker implies, it holds together experiences of repression and autonomy. ${ }^{10}$ The repetitious activity of pulling a threaded needle through a piece of cloth allows the stitchers to recede into their own interior worlds. Embroidery, therefore, is analogy for incarceration and domesticity, imprisonment and femininity. But the analogy applies only to the Holloway handkerchief and not to the one made in Armagh. That one was not embroidered. It is coloured not stitched. Patterns created with a felt tip pen are a modern adaption of older techniques of decoration, the residue of which is evident in the formal design: an emblematic centrepiece, surrounded by epigraphic forms. The different

\footnotetext{
${ }^{6}$ Parker 2012: 201

${ }^{7}$ Daly Goggin 2009: 17.

8 Daly Goggin 2009: 23.

${ }^{9}$ Daly Goggin 2009: 20. She quotes from GUSTAFSON Helen, 2002, Hanky Panky: An Intimate History of the Handkerchief, Berkeley, Ten Speed Press and SCHWAB David E, 1957, The Story of Lace and Embroidery and Handkerchiefs New York, Fairchild.

${ }^{10}$ Parker 2012: 10.
} 
techniques of decoration, the creation of lines rather than stitches, the substitution of pen for needle, ink for thread, is a disruption of a material practice often indicative of historical discontinuity. There is no unbroken tradition of jailed women's handkerchief making; no direct line of descent can be drawn from Holloway to Armagh if, as is often the case, a new technique signifies a historical break. ${ }^{11}$ Furthermore, the Armagh piece, unlike the Holloway one, is less obviously feminine; it is not made of silk: the large, white cotton square is a man's handkerchief.

\section{Historical conditions}

The Armagh handkerchief is one of hundreds of handkerchiefs decorated by republican and loyalist prisoners between the years 1971 and $1976 .{ }^{12}$ The overwhelming majority of these were made by republican men: they were the largest group of prisoners when the prison population was at its height in the early 1970s (Figures 4, 5). Handkerchief decoration was widely practiced in the early years of the conflict in and about Northern Ireland; the conflict, euphemistically described as "The Troubles", lasted approximately thirty, from 1969 to 1998 , that is, from the deployment of the British Army in Belfast and Derry to the signing of the Good Friday Agreement. This periodisation is contested, especially the point of the end of conflict, since the process of conflict-resolution is far from finished. Indeed, there remains "a conflict about what the conflict is about." ${ }^{13}$ A series of "multiple disagreements" can be divided into those that interpret the conflict as ethno-national or colonial in nature. ${ }^{14}$ Currently, ethno-national interpretations that posit differences of culture and identity between two communities (loyalists, unionists and

\footnotetext{
${ }^{11}$ The relationship between some English suffragettes and Irish nationalists should be noted here as well as that at least two of the female signatories, Dolours and Marion Price, had been held in Britain.

${ }_{12}$ Some handkerchief decoration extends beyond 1976, often practiced by remand prisoners.

${ }^{13}$ McGarry and O'Leary 1996:1-2.

${ }^{14}$ McGarry and O'Leary 1996:5; Tonge 2006:12-15.
} 
protestants on the one hand, republicans, nationalists and catholics on the other) as the cause of conflict are dominant in most political and public arenas, not least because the 1998 Good Friday Agreement, which instituted the present power-sharing or "consociational" arrangements for Northern Ireland's internal government, attempts balance the opposing demands and desires of two traditions. ${ }^{15}$ Colonial interpretations seek to reinstate the history of British intervention in Ireland, emphasizing the maintenance of Northern Ireland within the British state as a limited theatre of war between those seeking Irish independence (nationalists and republicans) and British forces. Importantly, the interpretation of the conflict is not only a matter of academic debate but manifested though its material culture. It is cast as colonial in and through the republican handkerchiefs whose makers articulated their imprisonment as an act of British repression (Figure 6).

Notwithstanding its opposing interpretations and unsettled ending, there is some agreement about how the conflict developed through three phases: reactive containment, criminalisation, normalisation or managerialism. ${ }^{16}$ The terminology for the last phase is most contested ${ }^{17}$ but this debate is outside the historical scope of this article since it is focussed upon the period of reactive containment, 1969 to 1976 , to which the Armagh handkerchief belongs. Here, it should simply be noted that different penal regimes defined each of the three phases and the strategies of each regime altered the material conditions of prisoners and their material practices, such as decorating handkerchiefs. ${ }^{18}$ Peter Shirlow and Kieran McEvoy described reactive containment as "characterised by the state's need to react to the outbreak of political

\footnotetext{
15 Tonge 2006: 26-29.

${ }^{16}$ See development of these definitions in Gormally, McEvoy, and Wall 1993 then Shirlow and McEvoy 2008: 26-32.

17 Corcoran 2006: 19.

18 Brown 2008:28.
} 
violence" and pithily summarised by them in the phrase "getting the enemy off the streets." They note that "the prisons", and this would include Armagh women's jail, were "one element in an overall counter insurgency strategy." Imprisonment served as a punishment for opposition to British rule and Unionist control over Northern Ireland, but its primary objective was to contain it; the detention of those suspects who were subsequently defined as "terrorists." Holding people as internees or sentenced prisoners removed them from the theatre of conflict into camps, jails, and ships that were, therefore, subject to "military security" 20 including British Army perimeter controls. Their overtly repressive function was a register of the political, even prisoner-of-war, status of the prisons and prisoners. The drive to contain conflict, initially through internment brought "in" ${ }^{21}$ by the Stormont Parliament in 1971 and continued with British Direct Rule, which began the following year. Internment, imprisonment without charge or trial, was sectarian. Of the 2,169 people interned only 109 were not from the catholic-nationalist communities from which republican groups derived their support. Internment demonstrated the continuity of state sectarianism between devolved Unionist and direct British government, which the Northern Ireland Civil Rights Association had organised to oppose. It was their march against internment on Sunday 30 January 1972 that became known as Bloody Sunday, after the Parachute Regiment of the British Army opened fire on the crowd and killed fourteen unarmed civilians.

In internment camps, such as Long Kesh, internees were held alongside sentenced prisoners and subject to the same conditions. A special category for politically motivated prisoners, those sentenced for conflict-related offences, was conceded by the

\footnotetext{
${ }^{19}$ Shirlow and McEvoy 2008: 26-7.

${ }^{20}$ Corcoran 2006: 19.

${ }^{21}$ The phrase used by catholic-nationalists. See Fairweather, McDonagh and McFadyean 1984: 197.
} 
then-Northern Ireland Secretary William Whitelaw in June 1972 following a 35-day hunger strike by republican male prisoners in Crumlin Road Gaol. Prisoners "on special category" did not have to wear a uniform or undertake work, and could receive more letters, parcels and visits than "ordinary" prisoners. It was regarded as equivalent to political status because such prisoners had more or less the same rights as those who were remanded or interned; that is, they too were treated as if they were not in fact convicted.

The prison population escalated in the period of reactive containment not only due to internment, which was phased out by 1975 , but through an expedited and politicised sentencing process contained in the Emergency Provisions Act (Northern Ireland) 1973. The Act contained a list, "Schedule 4", that drew together selected existing criminal legislation, from common law murder to "throwing or using petrol bombs", to define conflict-related offences. It also proscribed certain organisations and announced: "A trial on indictment of scheduled offences shall be conducted by the court without a jury."22 These no-jury courts, which came to be named after Lord Diplock, who chaired the commission that recommended them, also allowed convictions on uncorroborated confessions.

From the failure of reactive containment, most notably that the mass incarceration of communities became a cause of conflict, developed the strategy of criminalisation. Criminalisation was a penal rather than judicial policy. Sentencing process remained the same while the conditions within the jails changed: on 1 March 1976, "special category" was withdrawn. From this moment, sentenced prisoners would be subjected to a conventional or "normal" criminal regime most forcefully materialised by the requirement to dress in prison clothing. Republican male prisoners refused to

\footnotetext{
${ }^{22}$ Northern Ireland (Emergency Provisions) Act 1973, The General Public Acts, London: HMSO, 1974.
} 
wear "a convict's uniform," ${ }^{23}$ wrapped themselves in prison blankets, and began a collective prison protest, involving female republican prisoners despite their different clothing regimes. Prisons became increasingly important front lines in the conflict as republican prisoners reasserted their political status through the blanket then no-wash campaigns that culminated in the hunger strikes of $1980-1 .{ }^{24}$

\section{Material conditions}

It was the condition of political imprisonment towards the end of the reactive containment phase of the conflict that enabled the production of the Armagh handkerchief and many, many other handkerchiefs. Prisoners 'on special category' were self-organised; they sustained their own organisations within jails, such as "A" company formed in 1974, which enabled them to follow routines within the prison relatively autonomously and collectively. Within the restrictive architecture of a prison, political prisoners were able to take collective control over the shared spaces of the wing, dining room, association area or yard, enabling individual prisoners to exchange the skills and adopt the practices of a political craft. The creation of commemorative objects, such as decorating handkerchiefs, was one of a series of collective political practices or traditions of resistance. Much more widely commented upon was prisoners' participation in military drills and education programmes. Interned, remanded and special category prisoners were not required to work and thus could spend their time participating in activities that allowed them to maintain their political collectives, protecting themselves from the penal regime whilst they remained in the prison.

Thus the Armagh handkerchief is a record of political imprisonment within the British state. At the moment when the handkerchief was produced, the forty-five female

${ }^{23}$ Convict's uniform was the phrase popularised by Francie Brolly in the H Block song, 1976.

${ }^{24}$ McKeown 2001; Corcoran 2006 33-41; Shirlow and McEvoy 2008: 28-30. 
prisoners who signed their names on its fabric were among those recognised as political through the special category designation. The date of their collective imprisonment, 1976, occurs twice on the Armagh handkerchief; its numbers were marked out in felt tip on the banner and written in Biro pen along the bottom hem. Decorated in the year special category was withdrawn and political status de-recognised within the prison system, it is an alternative record, one of the continuity prisoners' political identity. In a similar fashion to Jane Terrero's Holloway handkerchief, the Armagh piece of cloth asserts the importance of a moment in time. The handkerchiefs are announcements that their date, 1912 or 1976 , is worthy of note, of historical and, therefore, political significance.

The use of handkerchiefs as celebratory historical records was in fact already well established before the earliest of these twentieth century dates; it developed with the technologies of printing on textiles. Braun-Ronsdorf's History of the Handkerchief, presents examples of decorated handkerchiefs dating from the late seventeenth century that carry the stamp of political history: peace treaties, Parliamentary Acts; military, religious and royal leaders; maps and engineering achievements. ${ }^{25}$ These handkerchiefs became a public national record. Such events would be widely reported in broadsheets and periodicals, on paper that carried the immediacy of news, but their imprint on cloth, for elite exchange of gifts or the souvenir trade, has greater permanence. They were incorporated into cloth and cast into history. The Holloway handkerchief could be considered an appropriation of an official act of commemoration and the Armagh piece a reactivation of a subversive practice, a tradition of resistance. Understood in this way, both perform a particularly powerful manoeuvre: to take a sanctioned form and use for an unsanctioned activity; it is a simultaneous recognition and rejection of authority.

${ }^{25}$ Braun-Ronsdorf 1967. 


\section{Borrowed form}

Decorating a handkerchief began with deciding its centrepiece. Republican prisoners drew upon the conventional, recognisable iconography of nation and religion: Celtic interlacing and crosses, maps of Ireland and Irish flags dominated their handkerchiefs. The metonym for affiliation to an army, the gun, is recurrent as is the emblem of incarceration, barbed wire (Figures 7, 8,9). The Armagh handkerchief with its tricolour overlaid with an AK47 is a typical cloth of its type. Centrepieces were designed; they are adaptations of popular iconography produced with the limited materials available within a jail. A stencil was created on greaseproof paper taken from prison kitchens or dining rooms. It was laid under a handkerchief pinned or stretched on a board or table to guide the maker's hand over a smooth, taut surface. Prisoners with drawing skills, combined with knowledge of established iconography and how to approximate it for fabric, produced stencils. These skilled handkerchief makers might create the centrepiece outlines for other prisoners, share their stencils or reserve them for their own handkerchiefs. Colour was added to its surface, staining the whole; the flattening effect of even blocks of colour offset a little by the depth of the perspectival shapes in the centrepiece design. The means to create colour, felt tip pens, was shared. One former prisoner recalls the demand for all shades of green. The national colour of Ireland was frequently used, always running out and then unavailable; the supply of pens, dependent upon donations of family or friends, was limited in jail. Imagery was always accompanied by words. All handkerchiefs presented writing. Mottos might be copied from a stencil but names and dedications were freehand and concluded the decoration of the handkerchief. ${ }^{26}$ Handkerchief decoration flourished in all the jails that held remanded,

\footnotetext{
${ }^{26}$ This account is based on discussions with republican handkerchief makers at the museum housed by Roddy McCorley Society where the Armagh handkerchief is held.
} 
interned or sentenced political prisoners: it was practiced in Armagh, Crumlin Road, Magilligan, Portlaoise, and especially Long Kesh. Kris Brown, author of the extensive Artefacts Audit: A Report on the Material Culture of the Conflict in and about Northern Ireland' notes that "material relating to the Prison experience is abundant."27

In its use of iconography, methods of creating colour, and formal organisation of word and image, there is nothing to distinguish the Armagh handkerchief from any of those made by republican men in Long Kesh, the largest jail for male prisoners. Why, then, is this handkerchief so easily recognised as a gendered object? Does its gender only rest upon the female names, the signatures of women? If, after analysis, the handkerchief is found to be a copy of male object, is it no longer a feminine thing? I would suggest that the Armagh handkerchief cannot be reduced to a mere reproduction of a male practice, not least because the coloured not stitched, written not embroidered, handkerchief is an appropriation of a female form. Interpretations of the Holloway handkerchief as an act of subversion or a performance of identity are premised, quite rightly, on the fact that textile production, particularly its finishing and decorative practices, is traditionally women's work. ${ }^{28}$ Republican men, successively collectively imprisoned over the twentieth century, had adapted available patterns of resistance: they borrowed a subversive stitch. ${ }^{29}$ Thus, as the forty-five women signed the decorated Armagh handkerchief, they incorporated themselves into a republican tradition of

\footnotetext{
${ }^{27}$ Brown 2008:28. Handkerchiefs appear in every British and Irish collection that attempts to record the experience of imprisonment during the 'The Troubles': national museums, British Army regimental or Northern Ireland Prison Service collections, republican or loyalist exhibitions. They are also regularly auctioned on eBay, see Purbrick, 2013.

${ }^{28}$ Parker 2012; Daly Goggin 2009.

29 One republican handkerchief held by National Museum of Ireland (http://www.museum.ie/en/list/the-collections-1.aspx) observes more closely forms found in the Holloway handkerchief, including attaching a commemorative postcard. 'In Memory of T. Darcy and J. McNeela/16 $16^{\text {th }}$ April 1940', uses embroidery threads to create blocks of colour for its emblems, the Irish flag and harp, but these are laid over the fabric, drawn by a needle but not in any recognisable or taught embroidery stitch. This handkerchief may help understand how the feminine practice of stitching was adapted by male prisoners before developing into colouring or staining with felt tip pens.
} 
resistance, borrowing the already borrowed stencilled replacement for the stitching practice. Borrowing is, of course, the practice of both tradition and resistance.

Handkerchiefs produced by both imprisoned men and women were also a register of the changing materials of their domestic decoration. A traditional, skilled and exclusively female domestic pursuit was supplanted by a contemporary, less skilled, domestic occupation performed by children: filling outlined shapes with colour from felttip pens. The highly specialised techniques of embroidery were not as widely practiced in the last quarter of twentieth century as they were in the first but some stitching skills could have been developed by jailed women even if no knowledge of needle and thread had been acquired from older female relatives or learnt at schools. Needlecraft and dress-making training was offered to female prisoners in Armagh jail ${ }^{30}$ but such skills were not transferred to handkerchief decoration. That they stencilled rather than stitched demonstrates that they sought to reproduce a recognisable republican form, a shared iconography rendered through the same decorative technique.

\section{A piece of cloth}

Whilst the decorative strategies deployed on the surface of handkerchief changed, the handkerchief did not. A square of fabric accorded with a commemorative capacity, it remains consistent. Close attention ought to be paid to the materiality of this piece of cloth. In the introduction to their edited collection of ethnographic essays, Cloth and the Human Experience (1989), Annette Weiner and Jane Schneider consider cloth as "a medium for social life in the most general terms" in the words of one reviewer. ${ }^{31}$ Another summarises that, for them, "Cloth not only symbolizes but also serves to consolidate

\footnotetext{
${ }^{30}$ Corcoran 2006: 25. Although male prisoner used prison workshop and its craft practices, such as woodwork, to create republican artefacts such as harps, needlework was not adapted by female prisoners in the same way.

${ }^{31}$ Barnes 1990: 739.
} 
social relations and mobilize political power." ${ }^{32}$ This highly significant social and political material is also gendered. Schneider and Weiner claim that "cloth is more closely associated with women than with men." ${ }^{33}$ The crude strategies of gender differentiation in the commodified handkerchief (large for men or small for women, straight, hard masculine hems or frilly, fragile feminine edges) are not sufficient to undermine the lasting historical relationships between women and cloth. Weiner recognises that "[w]omen are by no means universally the producers of cloth" but, she explains, "their important roles in these activities are found worldwide as is the symbolism of human and cultural reproduction that is associated with cloth and its reproduction." ${ }^{34}$ Women make, and represent the making, of material worlds, from the particular to the universal, the familial to the political or cosmological. "[C]loth", she and Schneider summarise, "evokes female power." ${ }^{35}$ They not only create cloth but control its circulation:

in many societies they monopolize all or most of the manufacturing sequence, giving them a larger role than men. Many societies also assign women, rather than men, to exchange or give the cloths that tie the living to the dead, the bride's to the groom's family, the politically dominant to their dependent clients. ${ }^{36}$

A handkerchief is just a piece of cloth, a simple square, an uncomplicated form that reveals the fundamental function of the material: because it mediates between body and world it can bind people together. It conducts the material and symbolic work of reproducing life, from protecting and presenting the body and the self to sheltering and sustaining communities and culture. No handkerchief is large enough to cover a body but as a piece of cloth, a simple square form, it functions as a representation of the capacity of cloth.

\footnotetext{
${ }^{32}$ Volkman 1991: 175.

${ }^{33}$ Weiner and Schneider 1989: 20.

${ }^{34}$ Weiner 1992: 47.

${ }^{35}$ Weiner and Schneider 1989: 21.

${ }^{36}$ Weiner and Schneider 1989: 3.
} 
The association of women and cloth demonstrated by Schneider and Weiner produces an affinity. They perform the same material and symbolic work of reproduction. For Schneider and Weiner, reproduction is by no means reduced to motherhood and is perhaps best understood as the preservation of life: maintaining social relationships over time. Cloth is used by women to remember ancestors, to make alliances, to continue familial and political lines. Importantly, the gendering of material that can envelop the human form does not fix its meaning, leaving it in a fundamental or unchanging state. Rather, it casts it as a highly charged symbolic site. For example, through cloth exchanges, often enacted by women, material is inherited; it is passed on. Once an object acquires the status of inheritance, other kinds of significance proliferate. ${ }^{37}$ Since cloth passes between the dead and living, past and present, it can carry the marks of time. Indeed, the prison handkerchiefs are a record of time. They express the experience of a moment in time. Thus, neither handkerchief is a remote act of commemoration. Their dates are not a reference to a distant political event brought closer to everyday life by printed cloth; the moments in time reproduced by the handkerchiefs are gatherings of groups of imprisoned women. The decoration of both the Armagh and the Holloway handkerchief brought together a group of women, created an occasion, turned a moment of time into one of significance. Their signatures, written and stitched, are an expression of their existence, there and then, with each other and within their jails. The production and preservation of the handkerchiefs, the making and keeping of a piece of cloth, are acts of holding onto the time of their gathering, which keeps that moment falling away into the past. The handkerchiefs halt time.

\section{Of the person}

\footnotetext{
${ }^{37}$ Weiner 1992: 3
} 
The Armagh and Holloway handkerchiefs are a record of individual participation in a collective. Active participation is demonstrated by signing and stitching their names, making their own interventions upon the cloth; the handkerchiefs are a testament to their individual and collective existences; it is a form of personification. Imprisonment is inevitably personal and de-personalising. As each body is locked away in Armagh, for example, a person is removed from the place where she is known and from the people who recognise her. Mary Corcoran estimates that "1,000 or so" women of the almost 4,000 "that passed though prison system between 1972 and 1998" were sentenced for "scheduled" offences. ${ }^{38}$ The names and places written on the Armagh handkerchief offers a glimpse of personhood behind the statistics of imprisonment.

Cloth is personal; its habitual use to cover and bind, shield and show, commences with an attachment to the person that continues as it surrounds the person's torso, limbs or head, separating them from other surroundings, containing their physical body in a material world. Handkerchiefs are held in the space between different material domains, indeed, much the same could be said of all cloth. Of the meanings that this particular piece of cloth, the handkerchief, has acquired over time many relate to its mediation of the physical and moral, private and public, personal and political. Handkerchiefs manifest an interior life to an exterior world; they express emotion. The feelings, desires or needs of a person are carried, and rather carefully kept, in a handkerchief: it can show civility, demonstrate love or grief; it can ask for sympathy. ${ }^{39}$ Each of these affective performances is gendered, refracted through lines of difference, which are perhaps most starkly evident in the invocation of sympathy.

\footnotetext{
${ }^{38}$ Corcoran 2006: 8.

39 For the most important instance of a white handkerchief in the conflict used to appeal for sympathy see Dawson, 2010.
} 


\section{In a name}

The gun in the centrepiece of The Armagh handkerchief is a display of force that disturbs some of the historical associations of this powerfully expressive fragile cloth. But the drawn outlines of the AK47 and the blocks of colour that demarcate the parts of the automatic assault rifle amend rather than entirely overturn the established meanings of the handkerchief. It remains an object of attachment; a personal thing. The line of writing along the bottom hem announces that it was Christine's; it was hers to give to Geordie and Bernadette. Christine would have gathered the signatures to create a souvenir of her time in prison to donate to her friends, family or supporters. The women who signed their names wrote them for her; they did so to help her mark the occasion of her imprisonment and to claim their place within the group of imprisoned women. The brief details that the signatories gave below their names, their length of sentence and their locality, provided a small sketch of their lives: their status as within the prison and where they belonged outside it: "Evelyn Brady A/Town 8 years", "Marie McCann, Falls Rd, 7yrs", "Philomena Lyttle, Derry, 8 years." The juxtaposition of sentence and locality connects time and place as destinations on a journey and suggests that locality as an explanation of sentence. Eight years for coming from Andersontown, the same time for living in Derry. These place names are catholic-nationalist areas and front lines in conflict in and about Northern Ireland.

As the women prisoners summarized their lives and signed their names for Christine, they identified themselves as members of the ' $A$ ' Company announced in black lettering along the banner. 'A' company was the Provisional Irish Republican Army's (IRA's) organisation within Armagh jail. The gathering of names that commemorated the occasion of the women's imprisonment was also a political declaration. More than this, it was an act of defiance. Of the female prisoners serving conflict-related sentences, $17 \%$, according to Mary Corcoran's figures, were jailed for 
"public order offences or membership of proscribed organisations as their main or sole conviction." ${ }^{\circ 0}$ Perhaps nine women who named themselves members of the IRA on the handkerchief decorated in Armagh jail were imprisoned for this very same "scheduled" offence: IRA membership. Moreover, most, if not all the conflict-related offences of ' $A$ ' Company would have been undertaken as members of the IRA or as part of the IRA's military campaign. The handkerchief, therefore, is an article of opposition to imprisonment, a rejection of the power of prison over a person. Whist within the restraining architecture of a prison, women used a fabric far more flimsy than solid walls to demonstrate that they were not made penitent.

Their political declaration, moreover, their unapologetic adherence to violent political struggle, does not quite overwhelm the feminine form of the handkerchief. Its contradictions pivot around its personal expression of political allegiance. Nor is this just a matter of inscription, altering the surface of the cloth without changing the material. Allegiance to the IRA is personalised through the handkerchief itself because it was a gift. Christine gave it to Geordie and Bernadette. All gifts may be considered personal objects to some extent: as they pass from the hand of one to that of another they acknowledge those persons and their relationship to each other. ${ }^{41}$ The Armagh handkerchief anticipates its recipients, Geordie and Bernadette. The time taken to create its centrepiece, to decorate it, to pass it between female prisoners for signing was devoted to them. Another moment in time added its record, layered into its threads.

\section{Tying}

The circulation of decorated handkerchiefs, just as their production, was an effect of conditions of political imprisonment. The greater numbers of visits and parcels received

\footnotetext{
${ }^{40}$ Corcoran 2006: 8.

${ }^{41}$ Mauss 1990.
} 
by prisoners with political status facilitated the exchange of objects, both permitted and proscribed, between prisoners, their family and supporters. Plain handkerchiefs could be given to prisoners because they were considered to be an essential component of dress. Thus, the particular properties of the handkerchief, a necessary cloth that was additional to clothing, ensured that it passed through the prison system. It is a spare square of cloth that guarantees appropriate appearance; it functions like a garment, keeping the body correctly dressed. A handkerchief patrols the surfaces of appearance; it removes dirt, wipes away the body's excretions onto its surface: mucus or blood that dribbles from the nose onto the face, sweat that leaks onto skin. It brushes food from the mouth and dust from clothes. It is on hand to ensure that "matter out of place" ${ }^{\prime 2}$ is moved. Dirt is hidden in the folds of the handkerchief then pocketed beneath clothing, protecting the propriety of the person. However, its additional status, its function as an essential extra to the clothed body, lends itself to appropriation; its capacity for secrecy suggests other uses.

While plain handkerchiefs were part of dress, decorated ones were not. The process of drawing, outlining, colouring and writing transformed a permitted object into a proscribed one. Irish tricolours could be banned under the Flags and Emblems (Display) Act (Northern Ireland) 1954 and guns declared membership of proscribed organisations. Decorated handkerchiefs were smuggled out of the prisons. Smuggling illicit objects, passing them from prisoners to their families during visits, was relatively easy while special category conditions prevailed, at least it was easy compared the subsequent period of criminalisation when body searches were more frequent, intrusive and punitive. The handkerchief's material properties, its light folding fabric facilitated these illicit transfers of the early 1970 s. Indeed, its ability to be smuggled determined, at least in part, its suitability to be decorated. The handkerchief was difficult to detect in a pat down

\footnotetext{
42 Douglas 1966.
} 
search, especially if wound along the thicker turns of fabric typical of trouser waistbands. Furthermore, at a time when political imprisonment was officially acknowledged, prison officers did not seek confrontations over prison traffic in commemorative objects.

Creases are still visible on the Armagh handkerchief. It was folded four times to be carried by a person at a sixteenth of its full size. Smuggled handkerchiefs, such as the Armagh piece, politicised fabric illicitly exchanged, then performed the work of gifts: they sustained prisoners' family relationships, tied people together despite the separation of imprisonment, and contributed to their family economy. ${ }^{43}$ They were passed to family members on special occasions, in much the same way as the presentation of printed cards mark important moments in lives of their recipients. Upon receipt, they were often displayed in the prisoner's family homes and some were framed to perform this function. Framed and unframed handkerchiefs were also auctioned to raise money for these families. Handkerchiefs circulated in prisoners' homes and their organisations; they fulfilled the function of currency; they were of an appropriately high value. Thus they contributed to a family economy; decorating and smuggling handkerchiefs to sustain relationships and to help with home finances was a familiar practice to the Armagh signatories as wives, sisters and daughters of male prisoners as well as prisoners themselves.

The meaning of handkerchiefs decorated by imprisoned men or imprisoned women are differently weighted; the attributes of gender loaded into male or female names, tempering the understanding of the politicisation of a personal thing. Decoration does not overturn the association of women with cloth. Thus the handkerchiefs remain contradictory. It is the Armagh handkerchief decorated by women that reveals the contractions of fragile and forceful cloth. It does not resolve them. Indeed, it is in these contradictions that meaning is continually reproduced.

\footnotetext{
${ }^{43}$ Komter 1996.
} 
BARNES, Ruth, 1990. Cloth and Human Experience by Annette B. Weiner and Jane Schneider Review. Man 25/4: 739-740.

BRAUN-ROSENDORF M., 1967. The History of the Handkerchief. Leigh-on-Sea. F. Lewis Publishers.

BROWN Kris, 2008. Artefacts Audit: a report on the material culture of the conflict in and about Northern Ireland. Belfast. Healing Through Remembering.

CORCORAN Mary, 2006. Out of Order: The political imprisonment of women in Northern Ireland 1972-1998. Devon. Willan Publishing.

DALY GOGGIN Mary, 2009. Fabricating identity: Jane Terrero's 1912 embroidered English suffrage signature handkerchief. In Women and Things: Gendered Material Strategies, ed. Mary DALY GOGGIN and Beth FOWKES TOBIN, 17-42. Farnham. Ashgate.

DAWSON Graham, 2010. Father Daly's White Hanky: survivor memories, collective memory and the postmemory of Bloody Sunday in the Irish Troubles. In The Politics of Cultural Memory, ed, Lucy BURKE, Simon FAULKNER and Jim AULICH, 230-252. Newcastle-Upon-Tyne. Cambridge Scholars Publishing.

DOUGLAS, Mary, 1966. Purity and Danger. London. Routledge and Kegan Paul.

DOUGLAS Mary and ISHERWOOD Baron. 1996. The World of Goods: towards an anthropology of consumption. London. Routledge.

FAIRWEATHER Elaine, Roisín MCDONAGH and Melanie McFADYEAN, 1984. Only the Rivers Run Free, London. Pluto Press.

GORMALLY Brian, Kieran Mcevoy and David WALL, 1993. Criminal justice in a divided society: Northern Ireland prisons. In Crime and Justice: a Review of Research vol. 17, ed. M. TONRY Chicago. Chicago University Press.

HOLBRAAD, Martin, Sari WASTELL and J.M. HENARE. 2007, eds. Thinking Through Things: theorizing artefacts ethnographically. London. Routledge.

KOMTER Aafke, 1996. Women, gifts and power. In The Gift: An Interdisciplinary Perspective, ed, 119-131.Aafke KOMTER, Amsterdam: Amsterdam University Press.

MAUSS Marcel, 1990, [1925] .The Gift: The Form and Reason for Exchange in Archaic Societies. London. Routledge.

MCGARRY, John and Brendan O'LEARY, 1996. Explaining Northern Ireland: broken images. Oxford. Blackwell.

MCKEOWN Laurence, 2001. Out of Time. Irish Republican Prisoners Long Kesh, 1972-2000. Belfast. Beyond the Pale Publications.

PARKER Rozsika, 2012, [1984]. The Subversive Stitch: embroidery and the making of the feminine. London. I. B. Tauris 
PURBRICK Louise, 2006. Long Kesh/Maze, Northern Ireland: public debate as historical interpretation. In Re-Mapping the Field: new approaches in conflict archaeology, ed. John SCHOFIELD, Axel KLAUSMEIER and Louise PURBRICK, ed, 72-80. Berlin-Bonn. WestkreuzVerlag.

PURBRICK Louise, 2007. Without Walls: a report on Healing Through Remembering's Open Call for Ideas for a Living Memorial Museum of the conflict in and about Northern Ireland. Belfast. Healing Through Remembering.

PURBRICK Louise, 2013. Trading the past: the material culture of Long Kesh/Maze, Northern Ireland Journal of War and Culture Studies, 6 /1. 58-74.

SHIRLOW Peter and McEVOY Kieran, 2008. Beyond the Wire: former prisoners and conflict tTransformation in Northern Ireland. London. Pluto Press.

TONGE, John. 2006. Northern Ireland. Cambridge. Polity.

WEINER Annette B, 1992, Inalienable Possessions: the paradox of keeping-while-giving. Berkeley. University of California Press.

WEINER Annette B. and Jane SCHNEIDER, 1989. Introduction. In Cloth and the Human Experience, eds. Annette WEINER and Jane SCHNEIDER, 1-29. Washington and London, Smithsonian Institution Press.

VOLKMAN, Toby Alice, 1991. Cloth and Human Experience by Annette B. Weiner and Jane Schneider Review. American Ethnologist 18/1: 175-176. 